Article

\title{
The Influence of Proactive Green Innovation and Reactive Green Innovation on Green Product Development Performance: The Mediation Role of Green Creativity
}

\author{
Yu-Shan Chen *, Tai-Wei Chang, Chun-Yu Lin, Pi-Yu Lai and Kuan-Hung Wang \\ Department of Business Administration, National Taipei University, 151, University Rd., San Shia, \\ New Taipei City 237, Taiwan; allain1105@yahoo.com.tw (T.-W.C.); chunyu@mail.ntpu.edu.tw (C.-Y.L.); \\ tinalai6993@gmail.com (P.-Y.L.); a0939723681@gmail.com (K.-H.W.) \\ * Correspondence: dr.chen.ys@gmail.com; Tel.: +886-286-741-111 (ext. 66681) \\ Academic Editor: Giuseppe Ioppolo \\ Received: 18 June 2016; Accepted: 17 September 2016; Published: 22 September 2016
}

\begin{abstract}
This study fills the research gap in the exploration of the relationships between both proactive and reactive green innovations and green product development performance, and examines the mediating effect of green creativity. Structural equation modeling (SEM) is utilized to test the hypotheses. From the sample of 146 valid respondents, the results show that proactive green innovation positively affects green creativity and green product development performance, and green creativity positively affects green product development performance. In addition, our findings also indicate that the relationship between proactive green innovation and green product development performance is partially mediated by green creativity. Accordingly, green creativity plays a critical role for companies to achieve a great green product development performance. However, reactive green innovation does not significantly influence green creativity and green product development performance. Companies should develop proactive green innovation rather than reactive green innovation in order to enhance their green creativity and increase their product development performance.
\end{abstract}

Keywords: environmental management; proactive green innovation; reactive green innovation; green creativity; green product development performance

\section{Introduction}

Along with industrial evolution and development, the negative effects derived from industrial activities on the environment have become a global issue [1]. In order to eliminate environmental pressure, the concept of environmental protection and management has gained attention in the corporate management agenda [2,3]. Nowadays, because green products are generally acceptable [4,5], and green management can be profitable, companies pay more attention to green product development and production $[2,6,7]$. "Green product development performance" is originally defined as the development of new ideas about green products, green services, green processes, or green practices that are judged to be original, novel, and useful [8]. Simply put, if companies plan to develop and produce green products successfully, incorporating the mindset of green management with the activities of green product development should be critical [6]. Chen et al. [9] defined "green innovation" as hardware or software innovation that is related to green products or processes, including innovation in technologies that are involved in energy-saving, pollution prevention, waste recycling, green product designs or corporate environmental management. In 2006, Chen et al. [9] found that investment in green product innovation and green process innovation was beneficial to businesses. That is, companies 
should recognize the value of the green innovation, and realize that once green products are more common in the world, green product development can be more prevalent accordingly [10]. In addition, the public is becoming aware of environmental issues, so green product development has obtained more attention [6]. The development of environmentally friendly products and services, which creates new products to meet the increasing consumer awareness of environmental protection, is the key to business success [11]. Although prior research has broadly discussed related issues regarding green product development performance, significant gaps exist with respect to the impacts of proactive and reactive green innovations on green product development performance. Therefore, we bridged the research gap by proposing a research framework with four novel constructs: proactive green innovation, reactive green innovation, green creativity, and green product development performance. Since green product development is increasingly important for firms in the era of environmentalism, the research framework was examined to help companies better understand how to improve their green product development performance through key factors such as green innovation and green creativity.

Several research steps were followed in this study. We summarize the literature on proactive green innovation, reactive green innovation, green creativity, and green product development first. Next, we conduct an empirical test to verify the relationships among these important variables. More specifically, based on the research framework, five hypotheses were proposed and examined. In the last part, we made conclusions and discussions about the findings, implications, and possible directions for future research.

\section{Literature Review and Hypothesis Development}

\subsection{The Positive Effect of Proactive Green Innovation on Green Creativity}

Chen et al. [12] stated that being proactive is to take initiative actions and to try to create advantages. Chen et al. [12] divide green innovation into two types: proactive and reactive green innovations. "Proactive green innovation" is defined as active environment-related innovation in order to take initiatives for new practices or products ahead of competitors, to decrease costs, to seize opportunities, to lead in the market, or to obtain competitive advantages [12]. Covin and Slevin [13] noted that being proactive is part of entrepreneurship, so they emphasized that a company with proactive strategies takes preemptive measures or introduces new products to become a leading competitor in the market. Along with the increasing importance of social environmental awareness, companies which focus on profits also need to consider environmental sustainability according to the environmental management and policy [14]. Sharma and Henriques [15] found that companies with positive attitudes toward environmental protection and management tend to adopt and take active actions voluntarily, and they are not just in compliance with the relevant environmental protection regulations. In order to prevent negative impacts on the environment, the proactive environmental management initiative involves forecasting future norms and social trends, and introducing various business operations and products [16]. Besides, proactive environmental management usually comes with innovative strategies, which provides companies more opportunities to win competitive advantages [17]. The advantages of green innovation include a lower cost of dealing with pollutants, reduced responsibility in law, increased productivity and effectiveness, higher business reputation, and more support from customers and stakeholders. With respect to proactive environmental management, companies are critical since they are supposed to commit to investing in innovation, organizational systems, products, and services for continuous recycling [18]. Creativity is defined as the imagination of new ideas about products, services, processes, or practices which are original, novel, and useful [8]. Innovation is the capability of introducing something new, while creativity is the act of conceiving something new [8]. Thus, there exists a significant difference between creativity and innovation. Creativity can result in superior corporate performance [19]. Besides, the increase of creativity can effectively enhance competitive advantages [20]. Thus, creativity is a key determinant of corporate competitiveness [19]. Green creativity is defined as the development of new ideas about green products, 
green services, green processes, or green practices that are judged as original, novel, and useful [8]. Chen et al. [9] proposed that green innovation enhances the performance of corporate environmental management. That is, the companies that use proactive environmental management can also have the initiative of green innovation. In the field of environmental protection, green creativity is the foundation of all green production. According to the above argument, we assert that proactive green innovation can positively influence green creativity and posit the following hypothesis:

\section{Hypothesis $1\left(H_{1}\right)$. Proactive green innovation is positively associated with green creativity.}

\subsection{The Positive Effect of Proactive Green Innovation on Green Product Development Performance}

Product development is important for companies either in an emerging market or in the current market [21]. Product development is a potential source of companies' competitive advantage, and it is also critical for the companies to reshape their image and face diversification in a rapidly changing market [22]. Krishnan and Ulrich [23] claimed that the product development is to convert market opportunities into products or services to meet the needs of consumers and other interested parties. How to integrate environmental issues into companies' product development and to comply with environmental regulations and market demand is a challenge for them. For example, Loureiro et al. [24] found that while females with children may pay a small premium for eco-friendly goods, other consumers are not always willing to pay a premium for environmental friendly products. In addition, Zhang et al. [25] argue that firms contemplating eco-innovation can be faced with a prisoners' dilemma where eco-innovation may be a losing strategy. Chen [26] argues that green product development aims at product design and innovation is needed to reduce the environmental burden, which is a systematic and innovative method to respond to environmental issues. Hence, the development of environmentally friendly products and services, trying to create innovative products to meet the increasing consumer awareness of environmental protection, is the key to business success [11]. Thus, we think that proactive green innovation is positively related to green product development performance and imply the following hypothesis:

Hypothesis $2\left(\mathrm{H}_{2}\right)$. Proactive green innovation is positively associated with green product development performance.

\subsection{The Positive Effect of Reactive Green Innovation on Green Creativity}

Azzone and Noci [27] believed that companies using the basic post-processing method are likely to take passive moves and just follow environmental laws. "Reactive green innovation" is defined as passive environment-related innovation in order to comply with environmental regulations, to adapt to stakeholders' requests, to react upon the changing environment, or to respond to competitors' challenges [12]. Lee and Rhee [28] stated that the companies with a passive attitude towards environmental policy tend to have a lower level of environmental responses, and sometimes they ignore environmental issues. The companies with non-active attitudes toward environmental management are most likely to just control pollution based on the law. Furthermore, the reactive environmental approach usually lacks top managers' support and relevant training for the employees, and takes action only when an environmental problem exists [29]. In contrast, customers can have some power to force companies to pay more attention to the environment to increase investments to cope with environmental problems. However, the passive attitudes of the companies will not be reversed even though the passive companies take on strategies to respond to their consumers' requests [30]. In brief, even the reactive strategy induces green innovation. However, unlike the proactive strategy, the reactive strategy only responds to customers' needs and competes with other companies based on the law. Thus, in the field of environmental protection, green creativity is critical for the development of the innovation process. Companies' passive but innovative actions towards the environment in order to comply with environmental regulations or adapt to the green needs of the stakeholders can 
positively affect green creativity. Accordingly, we argue that reactive green innovation is associated with green creativity and propose this hypothesis:

Hypothesis $3\left(\mathrm{H}_{3}\right)$. Reactive green innovation is positively associated with green creativity.

\subsection{The Positive Effect of Reactive Green Innovation on Green Product Development Performance}

Ayag [31] argues that product development is not only an important linkage between companies and markets, but also the basis for business success. This is, companies need to strategically manage their product development activities for being competitive in the market. If a company cannot effectively manage product development activities, that will not only position it at a competitive disadvantage, but it will also result in future business that is full of risks [32]. In addition, the development of green products, whether product differentiation or low-cost production, is likely to be an important source of competitive advantage [33]. Lumpkin and Dess [34] stated that the passiveness and reactivity are not identical: the former neglects or is unable to grasp the opportunity within the leading market; the latter is a timely response to boycott the competition. According to the above statement, in the area of environmental protection, to take reactive environmental management of enterprises, it will be up to the competitors to innovate and make timely adjustments to reflect and to be free from the adverse competitive environment. Based on the above discussion, we argue that reactive green innovation is associated with green product development performance and argue the following hypothesis:

Hypothesis $4\left(\mathrm{H}_{4}\right)$. Reactive green innovation is positively associated with green product development performance.

\subsection{The Positive Effect of Green Creativity on Green Product Development Performance}

Firms need to develop organizational creativity which is the main driver of innovation to find out innovative solutions [35]. Previous literature argues that one of the crucial factors of new product success is team creativity that can foster the development of new products by means of usefulness and novelty [36]. Creativity refers to organizational ideas that can result in better product development performance [37]. Moreover, an innovative product development team with outstanding creativity can effectively satisfy consumer needs and have excellent product performances [38,39]. Hence, creativity positively affects new product development performance [36,40].

From a customer's perspective, a creative idea is evaluated by target customers [41]. A new idea may effectively determine the performance of new product development [38]. Team creativity refers to group-level creativity which is developed by interactions of team members [42]. Team creativity is positively related to team performance [43]. For companies, team creativity is one of the major sources of innovation [44]. Therefore, previous literature argues that team creativity is positively associated with the new product development performance [19,20,38,40,45]. 'Green product development performance' refers to "the development performance of products that have less of an impact on the environment, are less detrimental to human health, are formed or part-formed from recycled components, are manufactured in a more energy-conservative way, or are supplied to the market with less packaging" [8]. Based on the above explanation, we assert the following hypothesis:

Hypothesis $5\left(H_{5}\right)$. Green creativity is positively associated with green product development performance.

According to this research framework, proactive green innovation and reactive green innovation can positively impact green product development performance. Furthermore, we claim that green creativity mediates the relationship between proactive green innovation and green product development performance. Accordingly, the antecedents are proactive green innovation and reactive feedback, and the outcome is green product development performance, whereas green creativity plays the role of mediation. We report the research framework in Figure 1. 


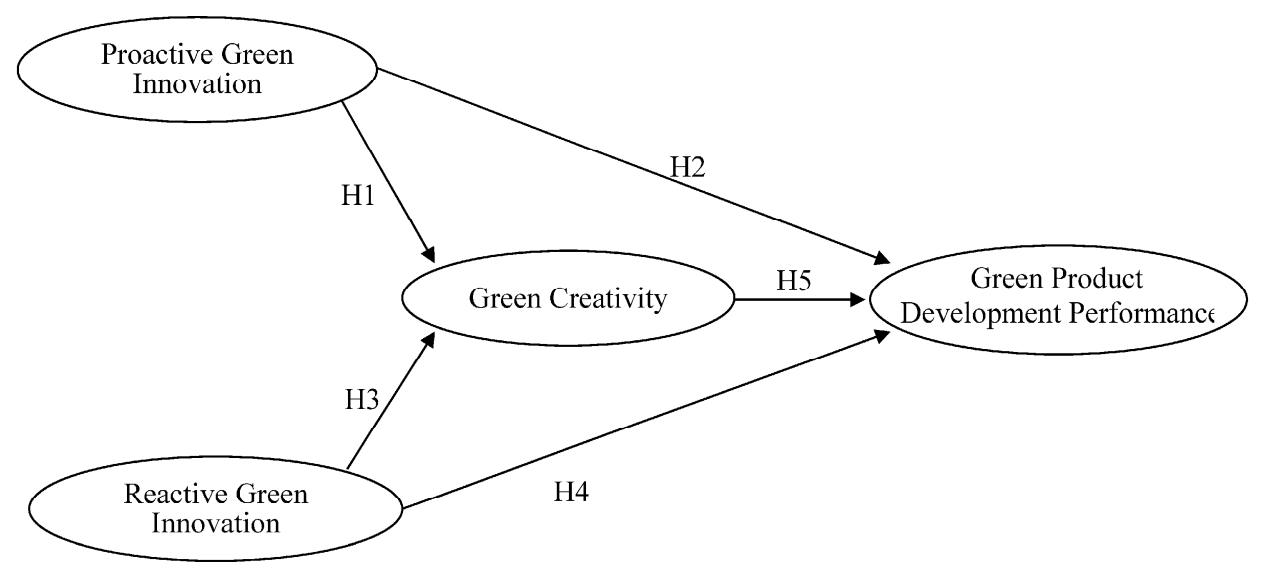

Figure 1. Research framework.

\section{Methodology and Measurement}

\subsection{Data Collection and the Sample}

We apply a questionnaire survey to verify the hypotheses in the Taiwan's manufacturing industry. The questionnaire survey was utilized by means of a postal survey to examine the hypotheses in the period from 1 October 2015 to 31 January 2016. The research participants were the employees who work in the companies in the electronics, information services, optoelectronic materials and components manufacturing, communication equipment manufacturing, biotech and health care, food manufacturing, textiles mills, machinery and equipment manufacturing, petrochemicals manufacturing, software industries and so on in Taiwan. The sample of questionnaire survey was randomly selected from "Business Directory of Taiwan". The respondents are CEOs, managers of manufacturing, environmental, $R \& D$, or marketing departments, and leaders and members of green product development projects. To increase the effective response rate, we called to every selected company to confirm the names and job titles of the respondents and to explain the objectives of the study and the questionnaire contents before questionnaire mailing. Moreover, we undertook two round pretests to ensure high level of content validity in this study. The respondents of different constructs in this study are different in order to reduce common method variance (CMV). This study asked every respondent to identify a particular green product development project that accounts for the most revenues for the company. Then, every respondent was asked to regard this green product development project as the focal one to assess its project team's "proactive green innovation", "reactive green innovation", "green creativity", and "green product development performance". The respondents of "proactive green innovation", "reactive green innovation" are members of green product development projects; those of "green creativity" are leaders of green product development projects; and those of "green product development performance" are CEOs or managers of manufacturing, environmental, $R \& D$, or marketing departments in the Taiwan's manufacturing companies. 180 questionnaires were distributed to the selected companies. There are 146 valid questionnaires, and the effective response rate is $37 \%$.

\subsection{Definitions and Measurements of the Constructs}

The questionnaire in this study consists of the four construct measurements such as proactive green innovation, reactive green innovation, green creativity, and green product development performance. The survey is a "tick the box" survey. We apply a five-point Likert scale that ranged from "strongly disagree" (1) to "strongly agree" (5) in the measurement of the questionnaire items.

Proactive green innovation. Based on prior research about proactive green innovation [12], "proactive green innovation" was defined as companies' proactive and innovative actions or strategies towards the environment in order to take new measures, have new products, reduce costs, grasp the 
opportunities, lead the market, and/or gain a competitive advantage. The measurement of proactive green innovation has four items: (1) Your company often actively has innovations about environmental protection then it can take new measures or have new products to have a lead over its rivals; (2) Your company actively engages in constantly betting on environmental innovation resources, successfully takes the opportunity to become a pioneer in the market; (3) Your company actively improves its production processes, reuses, recycles, and reduces the use of raw materials in order to cut costs; (4) Your company voluntarily implements innovations about environmental protection in order to obtain a competitive advantage.

Reactive green innovation. According to previous literature [12], "reactive green innovation" is defined as "companies' passive but innovative actions or strategies towards the environment in order to comply with environmental regulations, adapt to the needs of the interested parties, to respond to the changing environment, to respond to the challenges of competitors, and the negative correlation of environmental innovation". The four-item measure developed to measure reactive green innovation was: (1) Your company passively adopt environment-related innovations, in order to comply with environmental regulations; (2) Your company was asked to create new solutions to meet the needs of interested parties; (3) Your company was forced to respond to changing circumstances; (4) Your company will be passive and environment-related innovation, challenge to cope with competitors.

Green creativity. Referring to the notion of Chen and Chang [8] about green creativity, green creativity is defined as the development of new ideas about green products, green services, green processes, or green practices that are judged as original, novel, and useful. In order to measure green creativity, the measurement of green creativity contains six items [8]: (1) The members within the project propose new ways to realize the objectives of environmental protection; (2) The members within the project find out new green ideas to enhance environmental performance; (3) The members within the project advocate new green ideas to others; (4) The members within the project create proper plans for the implementation of new green ideas; (5) The members within the project would recheck new green ideas; (6) The members within the project would discover original solutions for environmental problems.

Green product development performance. This study refers to Chen and Chang [8] to develop the five-item measure of green product development performance including: (1) The project of green product development contributes significant revenues to the company; (2) The project invents outstanding green products; (3) The project continues to improve its development processes over time; (4) The project is more creative in green product development than its competitors; (5) The project can achieve its aims in green product development.

\section{Empirical Results}

\subsection{The Results of the Measurement Model}

Table 1 shows means, standard deviations, and positive correlations of the constructs in this study. Table 2 shows the factor analysis and suggests that every construct was just classified into one factor. Also, relevant research was reviewed and two pretests were employed for the content validity of the measurement. More specifically, several steps were taken to confirm the reliability and validity of the measurement. In Table 3, the loadings $(\lambda)$ of all items of the four constructs are significant, which indicates the good quality of the measurement model. In addition, Cronbach's $\alpha$ can be used as the index for the reliability, and the minimum requirement is 0.7 [46]. In Table 3, the Cronbach's $\alpha$ coefficients of all constructs are more than 0.7 , so the reliability of the measurement in this study is acceptable.

According to Fornell and Larcker [47], the average variance extracted (AVE) can be used as an indicator for discriminant validity of the measurement. To meet the requirement of the discriminant validity, the square root of a construct's AVE should be greater than the correlations between the constructs in the model. For instance, the square roots of the AVEs of proactive green innovation and 
green product development performance are 0.849 and 0.862 , respectively, which are greater than their correlation, 0.616 . Thus, there is adequate discriminant validity between the two constructs. The square roots of all constructs' AVEs in Table 3 of this study are all more than the correlations among all constructs in Table 1. Therefore, the discriminant validity of the measurement in this study is acceptable. In addition, if the AVE of a construct is higher than 0.5 , it means that the convergent validity of the construct is acceptable. In Table 3 , the AVEs of the four constructs, $0.721,0.707,0.748$, and 0.743 , are all higher than 0.5. It indicates that the convergent validity of the measurement is acceptable. Based on the above results, the reliability and validity of the measurement in this study are acceptable.

Table 1. Means, standard deviations, and correlations of the constructs.

\begin{tabular}{lccccc}
\hline \multicolumn{1}{c}{ Constructs } & Mean & Standard Deviation & A & B & C \\
\hline A. Proactive green innovation & 3.475 & 0.8725 & & & \\
B. Reactive green innovation & 3.623 & 0.8800 & $0.386^{* *}$ & & \\
C. Green creativity & 3.664 & 0.7989 & $0.605^{* *}$ & $0.319^{* *}$ & \\
D. Green product development performance & 3.144 & 0.8304 & $0.616^{* *}$ & $0.203^{*}$ & $0.659^{* *}$ \\
\hline & $* p<0.05,{ }^{* *} p<0.01$. & & &
\end{tabular}

Table 2. Factor analysis of this study.

\begin{tabular}{cccc}
\hline Constructs & Number of Items & Number of Factors & $\begin{array}{c}\text { Accumulation Percentage of } \\
\text { Explained Variance }\end{array}$ \\
\hline Proactive green innovation & 4 & 1 & $78.63 \%$ \\
Reactive green innovation & 4 & 1 & $77.92 \%$ \\
Green creativity & 6 & 1 & $79.81 \%$ \\
Green product development performance & 5 & 1 & $73.19 \%$ \\
\hline
\end{tabular}

Table 3. The items' loadings $(\lambda)$ and the constructs' Cronbach's $\alpha$ coefficients and AVEs.

\begin{tabular}{|c|c|c|c|c|c|}
\hline Constructs & Items & $\lambda$ & Cronbach's $\alpha$ & AVE & $\sqrt{\mathrm{AVE}}$ \\
\hline \multirow{4}{*}{ Proactive green innovation } & PGI1 & 0.875 & 0.902 & 0.721 & 0.849 \\
\hline & PGI2 & $0.906^{* *}$ & & & \\
\hline & PGI3 & $0.732 * *$ & & & \\
\hline & PGI4 & $0.871^{* *}$ & & & \\
\hline \multirow{4}{*}{ Reactive green innovation } & RGI1 & 0.838 & 0.860 & 0.707 & 0.841 \\
\hline & PGI2 & $0.887^{* *}$ & & & \\
\hline & PGI3 & $0.787^{* *}$ & & & \\
\hline & PGI4 & $0.850 * *$ & & & \\
\hline \multirow{6}{*}{ Green creativity } & GC1 & 0.881 & 0.949 & 0.748 & 0.865 \\
\hline & GC2 & $0.846^{* *}$ & & & \\
\hline & GC3 & $0.858^{* *}$ & & & \\
\hline & GC4 & $0.888^{* *}$ & & & \\
\hline & GC5 & $0.817^{* *}$ & & & \\
\hline & GC6 & $0.865 * *$ & & & \\
\hline \multirow{4}{*}{ Green product development performance } & GPD2 & 0.815 & 0.919 & 0.743 & 0.862 \\
\hline & GPD3 & $0.851^{* *}$ & & & \\
\hline & GPD4 & $0.855^{* *}$ & & & \\
\hline & GPD5 & $0.923^{* *}$ & & & \\
\hline
\end{tabular}

\subsection{The Results of the Structural Models}

The hypotheses were tested using SEM and AMOS. We report the results of the structural model in Table 4. The results show the fit of the full model is acceptable (GFI $=0.838$, RMSEA $=0.087$, $\mathrm{NFI}=0.892, \mathrm{CFI}=0.940$ ). We also demonstrate the results of the full model in Figure 2. Of five paths, 
only three paths estimated are significantly positive. Among these, $\mathrm{H} 1, \mathrm{H} 2$, and $\mathrm{H} 5$ are supported by this study. We find out that the increase of proactive green innovation can improve both green creativity and green product development performance. We prove that proactive green innovation is a crucial driver of green product development performance. Furthermore, we verify that the positive relationship between green product development performance and proactive green innovation is partially mediated by green creativity. It means that proactive green innovation positively influences green product development performance directly, and positively influences it indirectly through green creativity. Thus, we recommend that firms have to improve their proactive green innovation and green creativity to increase their green product development performance.

Table 4. The results of the structural model.

\begin{tabular}{cccc}
\hline Hypothesis & Proposed Effect & Path Coefficient & Results \\
\hline H1 & + & $0.687^{* *}$ & $\mathrm{H}_{1}$ is supported \\
H2 & + & $0.237^{*}$ & $\mathrm{H}_{2}$ is supported \\
$\mathrm{H} 3$ & - & 0.108 & $\mathrm{H}_{3}$ is not supported \\
$\mathrm{H} 4$ & - & -0.065 & $\mathrm{H}_{4}$ is not supported \\
$\mathrm{H} 5$ & + & $0.604^{* *}$ & $\mathrm{H}_{5}$ is supported \\
\hline \multicolumn{4}{c}{ Note: ${ }^{*} p<0.05,{ }^{* *} p<0.01}$.
\end{tabular}

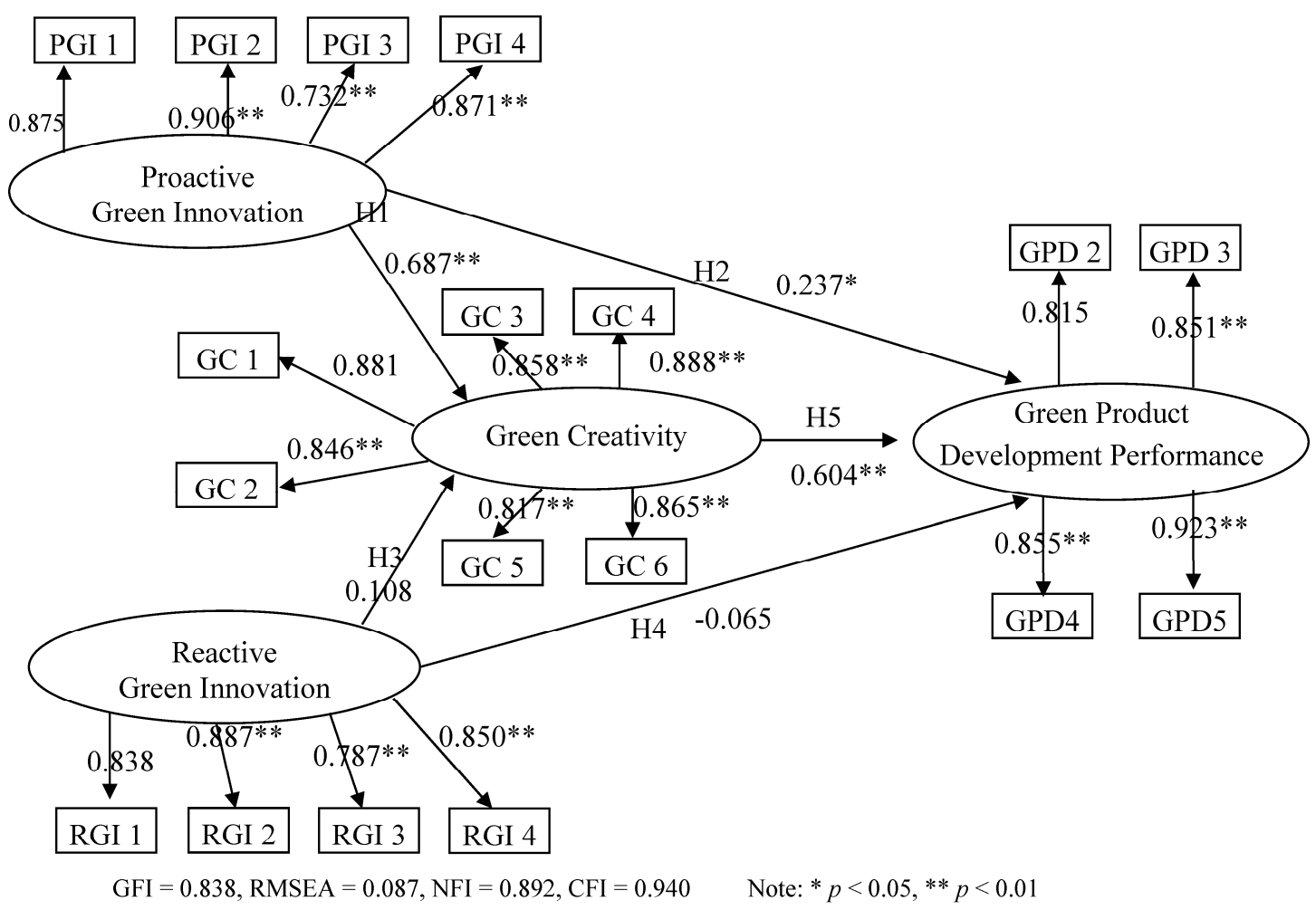

Figure 2. The results of the full model.

\section{Conclusions and Implications}

Due to the research gap between green product innovation and green product development performance, this study examined the research framework focusing on how proactive green innovation and reactive green innovation impact green product development performance through green creativity in this environmental era. According to the empirical results of this study, proactive green innovation was positively related to both green creativity and green product development performance. Also, green creativity plays a partial mediator between proactive green innovation and green product 
development performance. Namely, if companies make a large investment in resources and increase their proactive green innovation, they would have better green product development performance. Moreover, along with more proactive green innovation in companies, the results show that the relationship "proactive green innovation-green product development performance" is mediated by green creativity. However, reactive green innovation does not significantly influence green creativity and green product development performance. Thus, companies should develop proactive green innovation rather than reactive green innovation in order to enhance their green creativity and increase product development performance.

Our findings have four academic contributions. First, based on the academic findings on the relationship between green creativity and green product development performance [8], the present study further accumulates the knowledge in this realm by adding more relevant variables, such as proactive green innovation and reactive green innovation, as the antecedent variables in the research framework. Second, according to the empirical findings, we find out that the influence of proactive green innovation is different from that of reactive green innovation, which can fill the research gap in previous studies. Third, green creativity partially mediates the relationship "proactive green innovation-green product development performance", which indicates the critical role of green creativity when companies pursue green product development performance. Fourth, because reactive green innovation does not significantly influence green creativity and green product development performance, companies have to develop proactive green innovation rather than reactive green innovation to enhance green creativity and green product development performance.

Also, this study has four practical contributions that benefit companies' green product development. First, the results imply that proactive green innovation is important for green creativity as well as green product development performance. Thus, in order to enhance green creativity and even green product development performance, setting up goals, interventions, and strategies which can help the company become equipped with proactive green innovation is essential. Accordingly, if companies want to gain profits from green products, they should pay attention to building an organizational culture of proactive green innovation. For example, the companies should actively invest financial and non-financial resources for green innovation in order to keep their leading position in the market. The companies should be willing to make strategic plans, redesign work processes, save energy, and recycle valuable resources [48]. A "culture of proactive green innovation" would push change and competitiveness in the market. There is a new form of collective, the environmental governance, which would affect the performance of sustainability. Along with a culture of proactive green innovation, the outstanding performance of green product development can be expected. Second, due to the importance of a culture of proactive green innovation, some sophisticated approaches should be incorporated to enhance the employees' proactivity for green product innovation. For instance, companies can provide well-designed training to help employees have awareness of the proactive green innovation culture in the companies. Third, green creativity plays an essential role between proactive green innovation and green product development performance, so increasing green creativity in companies also matters. Some managerial interventions, such as team building, brainstorming competitions, or compensation plans for increasing green creativity might be good choices. Fourth, companies should incorporate proactive green innovation which can create green creativity in their business models for the success of green product development.

We propose four directions for future research. First, future research can apply a longitudinal study to discuss the differences of the research results in the different periods. Second, future research can be conducted in other countries and compared with this study. Third, future research can consider human resource practices in the conceptual framework, since the scope of this study does not contain human resource practices. Fourth, future research can gather public archival data to obtain results and compare them with this study.

Acknowledgments: The authors appreciate the funding and support from the Ministry of Science and Technology in Taiwan. The project number of this study is MOST 104-2410-H-305-070-MY2. 
Author Contributions: Yu-Shan Chen proposed the research framework and ideas. Tai-Wei Chang and Chun-Yu Lin analyzed the results and wrote the paper in English. Pi-Yu Lai and Kuan-Hung Wang made contributions to the literature review.

Conflicts of Interest: The authors declare no conflict of interest.

\section{References}

1. Chen, Y.S.; Chang, C.H.; Lin, Y.H. The Determinants of green radical and incremental innovation performance: Green shared vision, green absorptive capacity, and green organizational ambidexterity. Sustainability 2014, 6, 7787-7806. [CrossRef]

2. Chen, Y.S. Green organizational identity: Sources and consequence. Manag. Decis. 2011, 49, $384-404$. [CrossRef]

3. Chen, Y.S.; Chang, C.H.; Lin, Y.H. Green Transformational leadership and green performance: The mediation effects of green mindfulness and green self-efficacy. Sustainability 2014, 6, 6604-6621. [CrossRef]

4. Chen, Y.S.; Chang, C.H. Enhance green purchase intentions: The roles of green perceived value, green perceived risk, and green trust. Manag. Decis. 2012, 50, 502-520. [CrossRef]

5. Chen, Y.S.; Lin, Y.H.; Lin, C.Y.; Chang, C.W. Enhancing green absorptive capacity, green dynamic capacities and green service innovation to improve firm performance: An analysis of structural equation modeling (SEM). Sustainability 2015, 7, 15674-15692. [CrossRef]

6. Chen, Y.S. The drivers of green brand equity: Green brand image, green satisfaction, and green trust. J. Bus. Ethics 2010, 93, 307-319. [CrossRef]

7. Chen, Y.S.; Lin, C.Y.; Weng, C.S. The influence of environmental friendliness on green trust: The mediation effects of green satisfaction and green perceived quality. Sustainability 2015, 7, 10135-10152. [CrossRef]

8. Chen, Y.S.; Chang, C.H. The determinants of green product development performance: Green dynamic capabilities, green transformational leadership, and green creativity. J. Bus. Ethics 2013, 116, 107-119. [CrossRef]

9. Chen, Y.S.; Lai, S.B.; Wen, C.T. The influence of green innovation performance on corporate advantage in Taiwan. J. Bus. Ethics 2006, 67, 331-339. [CrossRef]

10. Chen, Y.S. The driver of green innovation and green image-Green core competence. J. Bus. Ethics 2008, 81, 531-543. [CrossRef]

11. Cronin, J.J., Jr.; Smith, J.S.; Gleim, M.R.; Ramirez, E.; Martinez, J.D. Green marketing strategies: An examination of stakeholders and the opportunities they present. J. Acad. Mark. Sci. 2011, 39, 158-174. [CrossRef]

12. Chen, Y.S.; Chang, C.H.; Wu, F.S. Origins of green innovations: The differences between proactive and reactive green innovations. Manag. Decis. 2012, 50, 368-398. [CrossRef]

13. Covin, J.G.; Slevin, D.P. Strategic management of small firms in hostile and benign environments. Strateg. Manag. J. 1989, 10, 75-87. [CrossRef]

14. Gladwin, T.N.; Kennelly, J.J.; Krause, T.S. Shifting paradigms for sustainable development: Implications for management theory and research. Acad. Manag. Rev. 1995, 20, 874-907.

15. Sharma, S.; Henriques, I. Stakeholder influences on sustainability practices in the Canadian forest products industry. Strateg. Manag. J. 2005, 26, 159-180. [CrossRef]

16. Aragon-Correa, J.A.; Sharma, S. A contingent resource-based view of proactive corporate environmental strategy. Acad. Manag. Rev. 2003, 28, 71-88.

17. Hart, S.L. A natural-resource-based view of the firm. Acad. Manag. Rev. 1995, 20, 986-1014.

18. Moss, T.W.; Neubaum, D.O.; Meyskens, M. The effect of virtuous and entrepreneurial orientations on microfinance lending and repayment: A signaling theory perspective. Entrep. Theory Pract. 2015, 39, $27-52$. [CrossRef]

19. Amabile, T.M. A model of creativity and innovation in organizations. Res. Organ. Behav. 1988, 10, $123-167$.

20. Barczak, G.; Lassk, F.; Mulki, J. Antecedents of team creativity: An examination of team emotional intelligence, team trust and collaborative culture. Creativity Innov. Manag. 2010, 19, 332-345. [CrossRef]

21. Calantone, R.J.; Vickery, S.K.; Dröge, C. Business performance and strategic new product development activities: An empirical investigation. J. Prod. Innov. Manag. 1995, 12, 214-223. [CrossRef] 
22. Brown, S.L.; Eisenhardt, K.M. Product development: Past research, present findings, and future directions. Acad. Manag. Rev. 1995, 20, 343-378.

23. Krishnan, V.; Ulrich, K.T. Product development decisions: A review of the literature. Manag. Sci. 2001, 47, 1-21. [CrossRef]

24. Loureiro, M.L.; McCluskey, J.J.; Mittelhammer, R.C. Will consumers pay a premium for eco-labeled apples? J. Consum. Aff. 2002, 36, 203-219. [CrossRef]

25. Zhang, T.; Gensler, S.; Garcia, R. A study of the diffusion of alternative fuel vehicles: An agent-based modelling approach. J. Prod. Innov. Manag. 2011, 28, 152-168. [CrossRef]

26. Chen, C. Design for the environment: A quality-based model for green product development. Manag. Sci. 2001, 47, 250-263. [CrossRef]

27. Azzone, G.; Noci, G. Seeing the environment as a source of change. J. Organ. Chang. Manag. 1998, 11, $94-111$. [CrossRef]

28. Lee, S.-Y.; Rhee, S.-K. The change in corporate environmental strategies: A longitudinal empirical study. Manag. Decis. 2007, 45, 196-216. [CrossRef]

29. Henriques, I.; Sadorsky, P. The relationship between environmental commitment and managerial perceptions of stakeholder importance. Acad. Manag. J. 1999, 42, 87-99. [CrossRef]

30. Liu, C.Y.; Wu, C.H. Environmental consciousness, reputation and voluntary environmental investment. Aust. Econ. Pap. 2009, 48, 124-137. [CrossRef]

31. Ayag, Z. An integrated approach to evaluating conceptual design alternatives in a new product development environment. Int. J. Prod. Res. 2005, 43, 687-713. [CrossRef]

32. Fitzsimmons, J.A.; Kouvelis, P.; Mallick, D.N. Design strategy and its interface with manufacturing and marketing: A conceptual framework. J. Oper. Manag. 1991, 10, 398-415. [CrossRef]

33. Orsato, R.J. Competitive environmental strategies: When does it pay to be green? Calif. Manag. Rev. 2006, 48, 127-143. [CrossRef]

34. Lumpkin, G.T.; Dess, G.G. Clarifying the entrepreneurial orientation construct and linking it to performance. Acad. Manag. Rev. 1996, 21, 135-172.

35. Halbesleben, J.R.B.; Novicevic, M.M.; Harvey, M.G.; Buckley, M.R. Awareness of temporal complexity in leadership of creativity and innovation: A competency-based model. Leadersh. Q. 2003, 14, 433-454. [CrossRef]

36. Chang, S.-C.; Tein, S.-W.; Lee, H.-M. Social capital, creativity, and new product advantage: An empirical study. Int. J. Electron. Bus. Manag. 2010, 8, 43-55.

37. Hunt, S.D.; Morgan, R.M. The comparative advantage theory of competition. J. Mark. 1995, 59, 1-15. [CrossRef]

38. Cooper, R.G. The dimensions of industrial new product success and failure. J. Mark. 1979, 43, 93-103. [CrossRef]

39. Deshpande, R.; Farlet, J.U.; Webster, F.E. Corporate culture, customer orientation, and innovativeness in Japanese firms: A quadrad analysis. J. Mark. 1993, 57, 23-37. [CrossRef]

40. Griffin, A. The effect of project and process characteristics on product development cycle time. J. Mark. Res. 1997, 34, 24-35. [CrossRef]

41. Ford, C.M. A theory of individual creative action in multiple social domains. Acad. Manag. Rev. 1996, 21, 1112-1142.

42. Pirola-Merlo, A.; Mann, L. The relationship between individual creativity and team creativity: Aggregating across people and time. J. Organ. Behav. 2004, 25, 235-257. [CrossRef]

43. Bain, P.; Mann, L.; Pirola-Merlo, A. The innovation imperative: The relationships between team climate, innovation, and performance in research and development teams. Small Group Res. 2001, 32, 55-73. [CrossRef]

44. Yoon, S.W.; Song, J.H.; Lim, D.H.; Joo, B.K. Structural determinants of team performance: The mutual influences of learning culture, creativity, and knowledge. Hum. Resour. Dev. Int. 2010, 13, 249-264. [CrossRef]

45. Smith, P.G.; Reinertsen, D.G. Shortening the product development cycle. Res. Technol. Manag. 1992, 35, $44-49$.

46. Hair, J.F.; Anderson, R.E.; Tatham, R.L.; Black, W.C. Multivariate Data Analysis; Prentice-Hall, Inc.: Upper Saddle River, NJ, USA, 1998. 
47. Fornell, C.; Larcker, D.F. Evaluating structural equation models with unobservable variables and measurement error. J. Mark. Res. 1981, 18, 39-50. [CrossRef]

48. Ioppolo, G.; Cucurachi, S.; Salomone, R.; Saija, G.; Shi, L. Sustainable local development and environmental governance: A strategic planning experience. Sustainability 2016, 8, 180-195. [CrossRef]

(c) 2016 by the authors; licensee MDPI, Basel, Switzerland. This article is an open access article distributed under the terms and conditions of the Creative Commons Attribution (CC-BY) license (http://creativecommons.org/licenses/by/4.0/). 